\title{
The Effect of Motivational Entrepreneurship on Business Performance of SMEs Moderated by Process Innovation.
}

\author{
Senen Machmud \\ School of Economic \\ Pasundan, Bandung, Indonesia
}

\begin{abstract}
This study aims to determine the effect of motivational entrepreneurship to the innovation process and the performance of entrepreneurs. The population in this study are two centers of business in Bandung: Sentra Rajut Binongjati (the knitting business center) and Sentra Kaos Suci (the t-shirts business center). The samples in this study are 154 SMEs owners. Data analysis techniques use Partial Least Square - Structural Equation Modeling. The results show that motivational entrepreneurship which consists of achievement motivation, risk propensity, and self-efficacy have significant effects either on the innovation process and the business performance. It indicates that the achievement motivation, willingness to take risks and self-efficacy can generate innovation processes and improve business performance.
\end{abstract}

Keywords: Achievement motivation; Risk propensity; Self-Efficacy; Innovation; Performance; SME.

\section{INTRODUCTION}

The role of entrepreneur has two approaches, such as micro and macro. In micro approach, the roles of an entrepreneur are as inventor and planner. As an inventor, entrepreneur discovers and create something new. Meanwhile, as a planner, entrepreneur act as a designer of new action and effort, plan new business strategies, plan ideas and opportunities for success, create new organizations, and many others. [1] In macro terms, the role of an entrepreneur is to create prosperity, equity of wealth, and job opportunity that serves as the engine of economic growth of the country. [2]

In general, SMEs in Bandung deals with some problems such as business competition, access to the capital, infrastructure, cost access to the raw materials, weather, marketing and technology $[3,4]$ needs knowledge, ability, and willingness to gain the success of a business. Definitely, it also needs the creativity to produce innovation that leads to competitiveness. Study by [5] proves that the ability of innovation has a positive effect on business performance. The same study [6] proves that innovative products have a significant effect on business performance in 5 (five) cities in Indonesia such as Solo, Sukoharjo, Jepara, Klaten, and Magetan. Therefore, some efforts to maintain business continuity and success in industrial activities can be accomplished by several strategic approaches: be objective, make it simple, focus on profitable markets, develop marketing plans, manage the labor effectively, create clear financial records, appreciate the cash money, avoid the repeated traps, and understand the entire business phases. [7] Development in entrepreneurship is related to creativity and innovation, which includes product research and development, price, place, and promotion. SMEs can grow and succeed because they have sufficient capability to create products and high-quality services and excellent in the market.

Innovation is a public pressure's desired result to change the performance of private organizations and public organizations. This is related to the expected better service. It is 
based on the effectiveness and efficiency. It becomes a necessity for businessmen to produce a better service - this is related to the main element of the entrepreneur. [8] The concept of innovative behavior model based on the opportunities, its resources and producing a possible action. [9] According to [10] the success of an entrepreneur is determined by innovation which ultimately can improve business performance.

Entrepreneurship Empowerment, closely related to the life and welfare improvement for local development by exploring the strategic potentials owned by SMEs. [11] In addition, the potential and role of entrepreneurship have proven to be resistant to various economic crises. SMEs' motivation of is an internal factor that is contained in the entrepreneur of MSMEs. Internal factor is the most dominant factor in influencing the business performance of SMEs. The internal factors from the internal company tend to be changed by businessmen which include resource availability, personal skills, entrepreneurship ability and ability to use internal resources effectively. [12] It is apart from the businessmen' demographic characteristic factors, human resources, and business experience. The external environment is the environment outside the organization. There are two perspectives to conceptualize the external environment. First, it is a perspective that views the external environment as a vehicle that provides resources. Second, the perspectives look at the external environment as a source of information. The first perspective is based on the premise that the external environment is a vehicle that provides a vital resource for the survival of a company. This perspective also contains the potential external that threaten the company's internal resources. Strikes, deregulation and some changes in legislation, potentially undermine the company's internal resources. The second perspective connects information with environmental uncertainty. Environmental uncertainty refers to external environmental conditions that are difficult to forecast changes. This is related to the ability of organizational members in decision making.

The increasing competitiveness of SMEs to produce good performance can be done by improving the quality of its internal human resources. This is due to the problems and challenges faced by SMEs need serious attention towards the impact of the high level of competition that can be overcome. The entry of imported goods from China due to the ASEANPRC (ASEAN) trade agreement with low prices also poses a threat to SMEs as well as the MEA agreement. [12] External problems which affect the businessmen need to be balanced by increasing their capacity and capability in enhancing competitiveness, performance, innovation, and business creativity in order to maintain and seek new markets that need to be improved and to create competitive advantage without degrading product quality. Business competitiveness can be enhanced by innovation processes so that they are able to meet customers' needs. [13]

[14] stated that motivation is a psychological process that evokes and directs behavior toward goal achievement or goal-directed behaviors. [15] argue that motivation is a process that plays a role in the intensity, direction, and duration of individual efforts toward achieving goals. Similarly [16] provide a definition of motivation as a force within the individual that influences the voluntary direction, intensity, and persistence of behavior. Intensity is related to how hard someone tries. This is the element that gets the most attention from us when it comes to motivation. Thus, it can be said that motivation is a boost to a series of processes of human behavior on achieving the goals. In motivation, there are some elements such as generating, directing, maintaining, showing intensity, continuing and having a purpose. McClelland [12] states, one of the individual encouragement to produce individual performance is the need for achievement. The drive for achievement is the desire or determination to work well or exceed the standard of achievement. The standards may become from self-achievement in the past (improvement); objective measures (results orientation); exceeding the others 
(competitiveness); challenging goals; or something that others have not done (innovation). This shows the drive to act better and more efficiently. There is an individual desire for making a significant achievement, mastering skills, controlling, or having high standards. Study by [17] prove that the ability possessed by SMEs can improve business performance. Results of research conducted by [18] prove that the desire for achievement is a strong predictor of business performance.

The courage to take risks is closely related to the courage to take risks due to the uncertainty in the business. This is related to the opportunities taken by the businessmen that will be implemented into a new thing. Research by [19] prove that the courage to take risks in business can be one factor of business success. Similar with [20] the research proves that the courage to take risks relates to business decisions and behaviors. The process of innovation can be obtained by having the courage to deal with risk failure in realizing the new ways for business performance. The new way is a process innovation that can enhance a company's ability to succeed in business competition. [21]

Self-efficacy relates to someone's ability to perform tasks. According to [22] self-efficacy relates to individual perceptions in relation to the possessed ability in completing the task. When the existence of self-efficacy associated with businessmen, it will result in selfconfidence in completing business goals which have connections with the uncertainty in the future. Uncertainty about the gained outcomes requires certain self-beliefs and competencies related to improving business performance. [23] The feelings of individual abilities will affect their perceptions, motivations, and performance. Learning makes someone able to increase knowledge, skills and positive behavior. [24] Learning outcomes can generate creative power by creating new processes in the business. Thus, effectiveness and efficiency can be achieved. The newness in the business process is expected to improve business performance and selfefficacy affects performance. [25] Also [26] prove that self-efficacy has a positive effect on performance.

Based on the background of the problems and the important role of SMEs, it is necessary to know the influence of entrepreneurship motivation to the process innovation and business performance. The purpose of this study is to determine the magnitude of entrepreneurial motivational influences that include achievement motivation, the courage to take risks and self-efficacy toward the process innovation and business performance. The results of the study are expected to contribute to the performance of businessmen as well as the development of science, especially in entrepreneurship.

\section{METHODS}

This research uses the exploratory method. It makes a picture about situation or phenomenon which is meant for causal-predictive analysis. The population of this research is businessmen in two industrial clusters in Bandung, Sentra Industri Rajut, and Sentra Industri Kaos. The sampling technique using purposive sampling on the entrepreneur of SMEs in which based on several criteria that are; 1) Business Owners, 2) Willing to fill out questionnaires distributed by researchers, 3) Minimum sample $10 \%$ of total population. Based on the primary data, the obtained population data is 1.300 businessmen. The number of respondents taken as a sample is 154 businessmen. The method of data collection was done by distributing questionnaires directly to the respondent in accordance with sample criteria that have been set. The research instruments for achievement motivation variable adopt the instrument from [27] which has been validated by [28]. The instruments consist of 5 items. Moreover, the variables of risk propensity adopt a General Risk Propensity (GRP) instrument that has been validated by [20]. 
They consist of 4 instruments. The self-efficacy variables are adopted from [29] consist of 6 instrument indicators. Variable instruments of process innovation are adopted from [21] with 6 instruments. Meanwhile, the business variables are adopted from [30] consist of 6 instruments.

\section{DATA ANALYSIS}

Data analysis is done to describe the research result about motivation factors of SMEs in Sentra Kaos Suci and Sentra Rajut Binongjati Bandung. The data processing the WarpPLS 5.0 software. Operational variables in this study are motivational variables of entrepreneurship innovation and business performance that include; Achievement motivation (ARC), risks propensity (RP), self-efficacy (SE), innovation (INNO) and business performance (Perform). The research instrument uses Likert scale technique. Data analysis techniques use Structural Equation Modeling (SEM), component based Partial Least Squares (PLS). Partial Least Squares (PLS) modeling is based on predictions that have non-parametric properties. The test is performed on the outer model by testing the validity through convergent validity, discriminant validity and average variance extracted (AVE). The structural model is evaluated by model uses path coefficients criterion for construct and t-test and significance of structural path parameter. [31]

\section{DISCUSSION}

The respondent's characteristics consist of $65 \%$ men, with mostly $46 \%$ aged 30-40 years. Moreover, the age of business is $67 \%$ between 0-5 years. Data analysis is done by entering all data of respondent and testing convergent validity, discriminant validity, and significance test. The calculation results show all indicators show the loading value of $>0.5$. Outer model test results show that the convergent validity, discriminant validity and significance test and outer test model meet all requirements as shown in Table 1 and Table 2, as follows; 
Table 1. Indicator variable research

\begin{tabular}{|c|c|c|c|c|c|}
\hline Indicators & Achievement & $\begin{array}{l}\text { Risk } \\
\text { Propensity }\end{array}$ & $\begin{array}{l}\text { Self } \\
\text { Efficacy }\end{array}$ & Innovation & Performance \\
\hline Ach_1 & 0.687 & & & & \\
\hline Ach_2 & 0.742 & & & & \\
\hline Ach_3 & 0.701 & & & & \\
\hline Ach_4 & 0.680 & & & & \\
\hline Ach_5 & 0.735 & & & & \\
\hline Risk_1 & & 0.800 & & & \\
\hline Risk_2 & & 0.733 & & & \\
\hline Risk_3 & & 0.770 & & & \\
\hline Risk_4 & & 0.763 & & & \\
\hline Self_1 & & & 0.533 & & \\
\hline Self_2 & & & 0.635 & & \\
\hline Self_3 & & & 0.726 & & \\
\hline Self_4 & & & 0.684 & & \\
\hline Self_5 & & & 0.579 & & \\
\hline Self_6 & & & 0.560 & & \\
\hline Ino_1 & & & & 0.652 & \\
\hline Ino_2 & & & & 0.678 & \\
\hline Ino_3 & & & & 0.605 & \\
\hline Ino_4 & & & & 0.868 & \\
\hline Ino_5 & & & & 0.663 & \\
\hline Ino_6 & & & & 0.773 & \\
\hline Kin_1 & & & & & 0.510 \\
\hline Kin_2 & & & & & 0.599 \\
\hline Kin_3 & & & & & 0.738 \\
\hline Kin_4 & & & & & 0.588 \\
\hline Kin_5 & & & & & 0.746 \\
\hline Kin_6 & & & & & 0.700 \\
\hline
\end{tabular}

Table 2. Value of discriminant validity

\begin{tabular}{|l|c|c|c|c|c|}
\hline Variables & $\begin{array}{c}\text { Achievemen } \\
\text { t }\end{array}$ & $\begin{array}{c}\text { Risk } \\
\text { Propensity }\end{array}$ & $\begin{array}{c}\text { Self } \\
\text { Efficacy }\end{array}$ & $\begin{array}{c}\text { Innovatio } \\
\text { n }\end{array}$ & $\begin{array}{c}\text { Performanc } \\
\text { e }\end{array}$ \\
\hline Achievement & 0.709 & & & & \\
\hline $\begin{array}{l}\text { Risk } \\
\text { Propensity }\end{array}$ & 0.047 & 0.767 & & & \\
\hline Self Efficacy & 0.106 & 0.023 & 0.596 & & \\
\hline Innovation & 0.144 & 0.099 & 0.247 & 0.705 & \\
\hline Performance & 0.370 & 0.309 & 0.265 & 0.326 & 0.653 \\
\hline
\end{tabular}


Table 3. Composite Reliability, Average Variance Extracted (AVE) and Cronbach Alpha

\begin{tabular}{|l|c|c|c|}
\hline Variables & $\begin{array}{c}\text { Composite } \\
\text { Reliability }\end{array}$ & AVE & $\begin{array}{c}\text { Cronbachs } \\
\text { Alpha }\end{array}$ \\
\hline Achievement & 0.835 & 0.503 & 0.753 \\
\hline Risk Propensity & 0.851 & 0.588 & 0.766 \\
\hline Self Efficacy & 0.762 & 0.555 & 0.728 \\
\hline Innovation & 0.854 & 0.597 & 0.793 \\
\hline Performance & 0.814 & 0.526 & 0.726 \\
\hline
\end{tabular}

Table 4. Results of Path Analysis and Significance Test

\begin{tabular}{|l|c|c|}
\hline Path Analysis & Path Coeffients & P Values \\
\hline Achievement -> Innovation & 0.254 & 0.000 \\
\hline Risk Propensity-> Innovation & 0.127 & 0.043 \\
\hline Self Efficacy -> Achievement & 0.190 & 0.001 \\
\hline Achievement -> Performance & 0.396 & 0.001 \\
\hline Risk Propensity -> Performance & 0.328 & 0.001 \\
\hline Risk Propensity -> Performance & 0.207 & 0.011 \\
\hline Innovation -> Performance & 0.218 & 0.008 \\
\hline
\end{tabular}

Table 5. R values of squares and R-squares adjusted.

\begin{tabular}{|l|c|c|c|}
\hline Variables & R squares & R squares adjusted & P Values \\
\hline Innovation & 0.160 & 0.137 & 0.000 \\
\hline Performance & 0.409 & 0.387 & 0.000 \\
\hline
\end{tabular}

The results of the entire model of research variables are as follows;

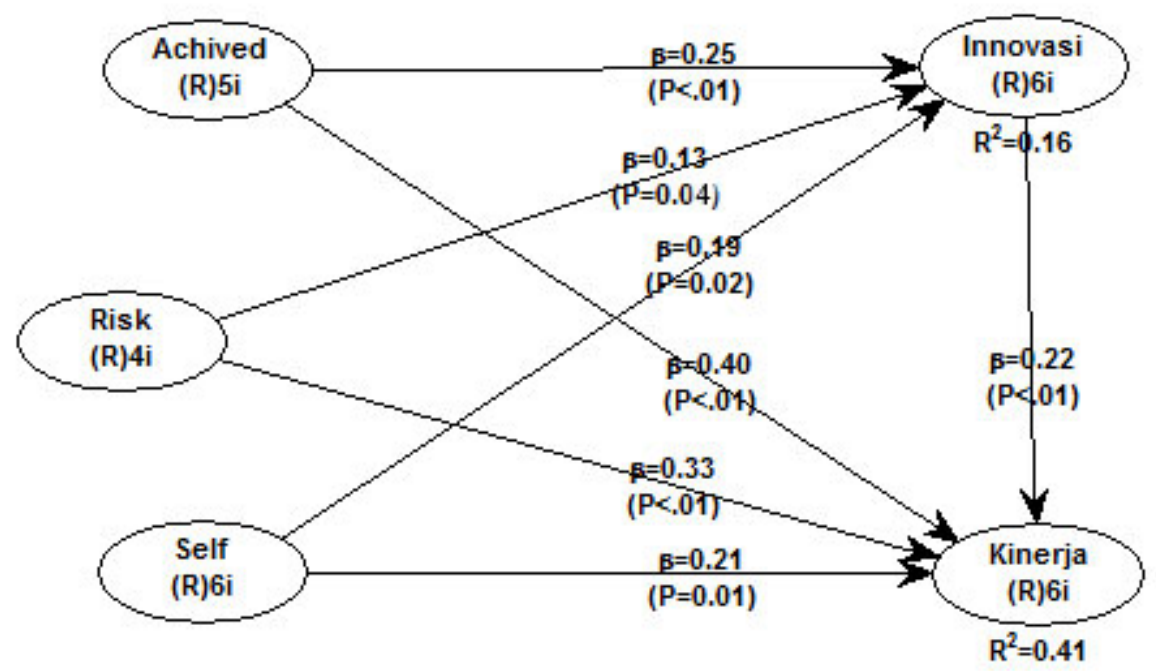

Figure 1. Results of Path Analysis

The picture above shows the results of research. It can be concluded that motivational entrepreneurship has a significant effect on innovation and performance. This is proven by the significant value below 0.05 for the achievement motivation, risk propensity and self-efficacy with the respective value, $0.01,0.02$, and 0.01 . The results of this study are in accordance with research [6] which prove that the orientation of entrepreneurship has a significant effect on product innovation. The research of [12] also proves that motivational entrepreneurship has a significant effect on the business performance. 
Motivational variables of entrepreneurship can improve the ability of process innovation and business performance. This is in accordance with [32] that state motivation is a series of forces that result in certain behaviors. To achieve high performance one must be willing to do something (motivation), must be willing to do the job effectively (ability) and have the material, resources, equipment and information to do the job. Mc. Clelland [12] states that there is a positive influence between motivation and individual performance. The higher the individual motivation for achievement, it will be easier in achieving maximum performance.

Motivational entrepreneurship is directly related the goal. In this case, it is the business objectives in order to improve the business performance of the entrepreneurs either directly or indirectly through process innovation. Motives of achievement, risk propensity, and selfefficacy directly affect the improvement of business performance. Achievement motivation will encourage the businessmen of SMEs in improving their enthusiasm in trying, never giving up on circumstances, taking risks and always improving their performance from time to time tirelessly. These achievement motifs will ultimately result in maximum business performance. The courage to face the risk in improving their business performance through process innovation contributes significantly to take some risks in generating innovation process. Selfefficacy enables businessmen to increase their knowledge, skills and positive behaviors to produce process innovations that ultimately can improve business performance. This is in accordance with a statement from [33] that self-efficacy relates to self-belief, competence, and ability to perform tasks in order to achieve certain goals.

The effect of innovation on performance proved to be significant with the p-value 0.01 . The results of this study support the innovation theory by Schrumpeter [34] which states that innovation as an product introduction or new product quality; Introduction of new production methods; This method is not always the result of major scientific discoveries, but can be the new ways to create products more efficiently; opening up a new market for a product; seeking new resources as raw materials for production, replacing existing resources; and creating new organizational structures at the industry level. The results of this study are in line with a research conducted by [6]. It proves that product innovation has a significant effect on the performance of SMEs in Central Java. Thus, it can be said that both product innovation and process innovation have a significant effect on the performance of SMEs. [2] suggest that innovation is the key to economic development of any organization and the structure of future development. Furthermore [35] states that when the company wants to produce extraordinary performance, then it is necessary to raise seven capitals including access to new ideas, role models, informal forums, special area opportunities, security networks, access to free markets and exclusive leadership. The company's capitals proposed by [35] implies that the role of creativity that can produce innovation is an important factor for the company's progress. This is relevant to SMEs' efforts to increase innovation in generating new processes resulting in optimum business performance. The new innovation process can drive business performance. It proves the new innovation process make the organizational process more effective and efficient.

\section{CONCLUSION}

Based on the results of the study, it can be concluded that motivational entrepreneurship has an influence on innovation and business performance. Similarly, the motivational variables of entrepreneurship and innovation have significant effects on the business performance. This indicates that the motivation factor of business including achievement motivation, courage to take decisions and self-efficacy contribute to the improvement of innovation and business performance. In addition, innovation variables contribute to improving business performance. 
This shows that the improvement of business performance can be done by increasing innovation supported by achievement motivation, risk propensity, and self-efficacy.

The managerial for business implied by developing achievement motivation, willingness to take risks in connection with the opportunity and having the ability of self-efficacy that improve the ability to produce a new process. Ultimately, it can improve the business performance. This study has some flaws since it does not use control variables. It only uses small samples. It is expected that the future research will include control variables, the other variables which are considered influential and a wider sample.

\section{References}

Suryana. 2009. Kewirausahaan, Pedoman Praktis: Kiat dan Proses Menuju Sukses. Jakarta: Penerbit Salemba Empat.

Hisrich, R. D., Peters, M. P., and Shepherd, D. A. 2008. Entrepreneurship: Kewirausahaan. Jakarta: Salemba Empat.

Sidharta, I., and Lusyana, D. 2014. Analisis faktor penentu kompetensi berdasarkan konsep knowledge, skill, dan ability (KSA) Di Sentra Kaos Suci Bandung. Jurnal Computech \& Bisnis. 8(1): p. 49-60.

Sidharta, I. and Lusyana, D. 2015. Pengaruh Orientasi Hubungan Dan Orientasi Tugas Dalam Kepemimpinan Terhadap Kinerja Pelaku Usaha. Jurnal Ekonomi, Bisnis \& Entrepreneurship, 9(1): p.45-55.

Battor, M., and Battor, M. 2010. The impact of customer relationship management capability on innovation and performance advantages: testing a mediated model. Journal of Marketing Management. 26(9-10): p. 842-857.

Ardyan, E. 2016. Market Sensing Capability and SMEs Performance: The Mediating Role of Product Innovativeness Success. DLSU Business \& Economics Review. 25(2): p. 79-97.

Machmud, S., and Sidharta, I. 2014. Business Models For SMEs In Bandung: Swot Analysis. Jurnal Ekonomi, Bisnis \& Entrepreneurship, 8(1): p. 51-61.

Amir, M. T. 2016. Corporate Entrepreneurship \& Innovation, Melejitkan Semangat Intrapreneurship di Organisasi. Jakarta: Prenada Media Group.

Sarasvathy, S. 2001. Causation and Effectuating: Toward a Theoritical Shift from Economic Inevitability to Entrepreneurial Contigency. Academy of Management Review. 2(6): p. 243-245.

Ireland, R. D., and Webb, J. W. 2007. Strategic entrepreneurship: Creating competitive advantage throught streams of innovation. Business Horizons. 50(1): p. 49-59.

Machmud, S., and Sidharta, I. 2013. Model Kajian Pendekatan Manajemen Strategik Dalam Peningkatan Sektor UMKM Di Kota Bandung. Jurnal Computech \& Bisnis. 7(1): p. 56-66.

Machmud, S., and Sidharta, I. 2016. Entrepreneurial Motivation and Business Performance of SMEs in the SUCI Clothing Center, Bandung, Indonesia. DLSU Business \& Economics Review. 25(2): p. 63-78.

Anderson, N., Potočnik, K., and Zhou, J. 2014. Innovation and creativity in organizations: A state-of-the-science review, prospective commentary, and guiding framework. Journal of Management. 40(5): p. 1297-1333.

Kreitner, R., and Kinicki, A. 2014. Perilaku Organisasi. Jakarta: Salemba Empat.

Robbins S. P., and Judge, T. A. 2011. Organizational Behavior. New Jearsey: Person Education Inc,.

McShane, S. L. and Von Glinow, M. A. 2015. Organizational Behavior, Emerging Knowledge, Global Reality. Mc Graw Hill Education.

Hadian, D., Senen Machmud, D. J., and Sidharta, I. 2015. Human performance in cluster center of clothing Bandung, Indonesia. International Journal of Applied Business and Economic Research. 13(6): p. 4417-4435.

Lijun, W., et al., 2014. Hair dressing entrepreneurs motivation, personality and business performance research. International Journal of Business and Management. 9(7): p. 126-138.

Chen, M., and Chang, Y. 2013. The impacts of human capital in enhancing new venture`s performance: competence, motivation and creativity. Journal of Knowledge-based Innovation in China. 5(2): p. 146-168.

Hung, KT., et al., 2012. Robustness of general risk propensity scale in cross-cultural settings. .Journal of Management Issues. 1: p. 78-96.

Wong, P. K., and He, Z. L. 2003. The moderating effect of a firm's internal climate for innovation on the impact of 
public R\&D support programmes. International Journal of Entrepreneurship and Innovation Management. 3(5-6): p. 525-545.

Wood, R. E., and Bandura, A. 1989. Social cognitive theory of organizational management. The Academy of Management Reviews. 14(3): p. 361-384.

Baum, J, R., Locke, E. A., and Smith, K. G. 2001. A multidimensional model of venture growth. Academy of Management Journal. 44(2): p. 292-303.

Gibson, J. L., Ivancevich, J. M., and Donnelly, Jr., J. H. 2012. Organizations. New York: McGraw Hill.

Hmieleski, K. M., and Baron, R. A. 2008. When does entrepreneurial self efficacy enhance versus reduce firm performance?.Strategic Entrepreneurship Journal. 2(1): p. 57-72.

Poon, J, M, L., Ainudin, R.A., and Junit, S. H. 2004. Effects of self-concepts traits and entrepreneurial orientation on firm performance. International Small Business Journal. 24(1): p. 61-80.

Taormina, R. J., and Lao, S. K. M. 2007. Measuring Chinese entrepreneurial motivation. International Journal of Entrepreneurial Behaviour and Research. 13(4): p. 200-221.

Jayawarna, D., Rause, J., and Kitching, J. 2011. Entrepreneur motivations and life course. International Small Business Journal. 31(1): p. 34-56.

Chandler, G. N., and Jansen, E. 1997. Founder self efficacy and new venture performance: a longitudinal study. Academy of Management. Best Papers Proceedings, p. 98-102.

Wiklund, J., and Shepherd, D. 2005. Knowledge based resources, entrepreneur orientation and the performance of small and medium size business. Strategic Management Journal. 24: p. 1397-1314.

Kock, N., 2012, WarpPLS 5.0 User Manual. http://cits.tamiu.edu/WarpPLS/UserManual_v_5_0.pdf

Moorhead, G., and Griffin, R. W. 2013. Organizational behavior: managing people and organizations $9^{\text {th }}$. Singapore: Cengage Learning Asia Pte Ltd.

Schhermerhorn, Jr, J. R., et al., 2011. Organizational Behavior. New Jersey: John Wiley \& Sons, Inc.

Reniati. 2013. Kreativitas Organisasi \& Inovasi Bisnis, Implementasi pada IKM Berbasis Kreativitas dan Budaya Menuju Keunggulan Bersaing Global. Bandung: Alfabeta.

Venkataraman, S. 2004. Regional Transformation through Technological Entrepreneurship. Journal of Business Venturing. 19(1): p. 153-167. 